\title{
Addiction, Ground Rents, and Urban Casino Development
}

\author{
Critical Gambling Studies Blog Entry by Martin Young and Francis Markham
}

Visit an interactive version of this blog at:

https://criticalgamblingstudies.blogspot.com/2020/01/addiction-ground-rents-and-urbancasino.html

Casino development has become a favoured urban development strategy in a number of postindustrialising western economies (Hannigan, 2007). These developments are often justified on the basis that casinos attract reputedly rich and super-rich consumers from other places in what amounts to a rather convenient geographical transfer of value. These wealthy consumers, so the mercantilist argument goes, enrich both the casino owners and the broader public through taxes and license fees. Moreover, these gambling dollars are imported, while the effects and responsibility for problem gambling, one of the key arguments against gambling developments, are conveniently exported. A second argument, particularly favoured by the gambling industry and other casino proponents, is the creation of local jobs, both in construction and subsequent casino operations. For example, the Canadian casino operator Gateway Casino and Entertainment has organised its new casino proposal for London, Canada, around the creation of 700 local jobs. More generally, neoclassical economists suggest that casinos tend to increase economic growth in the longer-term (e.g. Walker, 2007). A third argument is that casinos bring a certain symbolic value to a city, particularly if they take the form of large towers such as Barangaroo, Sydney, or its proposed competitor in Star City Casino located across the harbour in Pyrmont.

However, none of these explanations adequately explain why casinos in particular are so important to the contemporary development strategies of so many capitalist cities, especially since wide-spread casino liberalisation has made attracting lucrative high-rollers increasingly competitive. Casinos can only attract consumers from other places when legal casinos are not widespread. In the presence of extensive legalisation, urban spatial monopolies are broken and gamblers can gamble at home. Thus, while the strategy of casino-led urban development was feasible for Las Vegas and Macau, it cannot simply be replicated elsewhere, as the dwindling fortunes of Atlantic City have shown (Peck, 2016; Peck, 2017). Furthermore, urban casinos rely on addicted, local gambling-machine players for the lion's share of their profits in many locations. Similarly, casinos are notoriously small employers relative to their income, providing fewer jobs even than the hospitality sector in general. And symbolic architecture could arguably be better accomplished if not constrained by the distinctive architectural requirements of casino operators.

We argue that there is another, more important, reason that casinos are especially well-suited to urban development agendas - and that is their linkage to ground rents. Here it is useful to deviate into a less-known area of political economic theory, namely the way in which, according 
to Marxian theory, surplus profits are transformed into ground rents. For Marx (1981 [1894]: 914), ground rents are payments by capitalists to landowners simply for their permission to use the land for some productive purpose:

All this means in actual fact is that, under the given conditions, the ownership of these square feet of land enables the landowner to seize a certain amount of unpaid labour, which capital has realized by rooting in the soil like a pig in potatoes.

This means that landowners draw off a part of the profits from commodity production simply by right of their ownership of landed property. The reason rents can be extracted, according to Marx, is that landed property forms the necessary basis of all production and consumption, and its ownership by a particular class means that profits needed to be shared with this group if any production is to be possible.

However, there is one form of rent that Marx argues only occurs under special circumstances - a form of rent he termed monopoly rent. Here it is high buyer demand for a commodity of limited supply that drives the market price of the commodity above its value. The owner of the land used to produce the commodity is able to commandeer a portion of these surplus profits as monopoly rent. Marx (1981 [1894]: 910-911) provides the famous example of a vineyard producing a special vintage wine:

By monopoly price here we mean any price determined simply by the desire and ability of the buyer to pay, independently of the price of the product as determined by price of production and value. A vineyard bears a monopoly price if it produces wine which is of quite exceptional quality but can be produced only in a relatively small quantity. By virtue of this monopoly price, the wine-grower whose excess over the value of his product is determined purely and simply by the wealth and the preference of fashionable wine-drinkers can realize a substantial surplus profit. This surplus profit, which in this case flows from a monopoly price, is transformed into rent and accrues in this form to the landowner by virtue of his title to the portion of the earth endowed with these special properties. Here, therefore, the monopoly price creates the rent.

Marx did not give much attention to these rents in his notes (which became Capital Volume III) because they were produced by the vagaries of supply and demand rather than the general motion of capital - the production, circulation and supply of value - that he was primarily concerned with. However, in more recent years, it has become clear that monopoly prices have emerged as important basis for ground rents. David Harvey (2012), for example, has 
emphasised how important these rents have become to the tourism industries and to the social construction of places in general.

We argue that there are two ways in which monopoly rents have become centrally important to the gambling industries. First, casinos and other gambling venues achieve monopoly prices for the commodities they produce because of the increased desire of addicted consumers. Indeed, an orthodox definition of problem gambling is based on "... difficulties in limiting money and/or time spent on gambling leading to adverse consequences for the gambler, others, or for the community ..." (Neal et al., 2005: i). In other words, the production of gambling commodities involves what Adams and Livingstone (2015) refer to as an 'addiction surplus' - an economic surplus that is generated through over-consumption. A similar argument regarding the production of coercive or akratic commodities is made by Young and Markham (2017). The surplus profits so produced increase the amount of ground rents that the landowner of a casino site can extract as payment. In many cases, of course, the casino operator buys the land and thus internalises this rent relation, vastly adding to their profits.

The key point is that a monopoly price for gambling commodities produces a quantum of ground rent over-and-above what would be ordinarily received by non-addictive or non-akratic forms of production or consumption. These monopoly rents are highly sought by landowners who engage in the rent-seeking behaviour associated with casino development interests. We would argue that this ability for casinos to produce monopoly rents is one reason they are uniquely attractive to an ensemble of urban actors with vested property interests.

While monopoly rents produced via addiction could explain why casino land becomes more valuable, urban casino development in recent years has tended to take place on prime public land, whether that be the waterfront of Singapore or Sydney. In other words, casinos have been built on land that was already amongst the most valuable in the world. These prime urban locations already bear a very high potential monopoly rent. Or more precisely, it is land that would be highly valuable if it were able to be brought into private ownership and bought and sold on the market given that the price of land is derived from "expectations of future rents" (Harvey, 2012: 28). Consequently, this land is highly desired by multiple potential buyers (e.g. for luxury residential or commercial uses) who have an ability to pay underwritten by access to global finance markets. The main problem for developers is that this is often public land under state control and not released to the market, in part because of its importance to the city as a whole.

Casino development is one way around this. Casino urbanism with its promise of jobs, economic development and high-rollers landing in private jets provides rhetorical cover for the appropriation 
of prime public space by gambling capital. This 'new enclosure' of the most valuable public land in a city is premised on the necessity of these prime locations for the success of a casino.

But casino developments are rarely only casino developments. They often include private apartment towers and retail spaces which are sold at very high prices. In these cases, urban casino developments rely on what is essentially real estate development to underwrite their profitability, furnishing the "real estate state" (Stein, 2019) with an excuse to facilitate private property development in desirable urban locations. Whether this occurs through the privatisation of public lands or through tweaks to or exemptions from urban planning rules, vast financial wealth is created through the production of an anticipated stream of future ground rents. The astronomical land prices that these developments are able to command are, of course, a function of the captured monopoly ground rents.

These two expressions of monopoly rent, one that increases the value of land through addictive gambling, the other that appropriates prime land under the guise of necessary urban development, are cumulative and interactive. Addiction or akrasia-generated rents are likely to apply to all gambling venues to various degrees including those in prime urban locations. And the discursive logics of casino capital will continue to be employed to enclose and appropriate the most valuable urban locations as a neoliberal form of real estate development.

State power is necessary to the production of both strands of this monopoly rents project. State power needs to be activated in order to provide the necessary planning and regulatory permissions for casino developments. The state also acts to privatise and sell-off urban space to the gambling industries, as well as through the provision of a planning system which balances the competing needs of different fractions of capital for access to urban land. This occurs even in the face of documented gambling harms partly because the state powers have been captured by gambling and real estate interests, and partly because the state is a direct beneficiary of increased land prices (via higher land taxes) and sale fees for the land itself. For these reasons, the state tends to allow gambling harm to rise to the maximum level that civil society will tolerate, relegating gambling-related public-health to a largely discursive and abrogative affair (Young \& Markham, 2017). Indeed, urban land development strategies, such as the ones outlined at the start of this article, are predicated on the maintenance of high levels of gambling harm as their necessary precondition.

We have outlined, in an abstract and stylised way, two mechanisms through which ground rents are corralled by urban casino developers to reap windfall profits. However, casino developments take place in concrete urban geographies rather than the abstract space of political economy, and thus intersect with other forms of social domination, particularly race. Racialisation crosscuts 
the economic geographies of urban casino development. The dominant racial trope evoked when urban casinos are promoted as attracting an international clientele is the "Chinese high roller". These figures are simultaneously constructed as clever entrepreneurs (and thus able to lose large fortunes without suffering harm) and as useful idiots amenable to fleecing. This expression of "Orientalism" (Said, 1979), designed to legitimate what would otherwise be seen a form of exploitation, should not be surprising. Mercantilism, after all, is the economics of empire, and it is hardly the first time that colonial logics have justified the export of harmful and addictive commodities from the West to China (Lowe, 2015).

However, in settler colonies like Australia where race is produced primarily through the expropriation of land rather than relations of slavery (Wolfe, 2016), and where dispossession rather than proletarianisation is the dominant form of oppression for Indigenous peoples (Coulthard, 2014), questions of land rights and sovereignty always haunt discussions of rent. Here, the 'public' lands privatised via casino developments have been violently wrested from Indigenous peoples. Ground rents are extracted from stolen Indigenous land. In this context, the extraction of surplus profits not only implicates relationships between gamblers and casino capitalists, and capitalists and landlords, but also, in settler colonial states, operates through the expropriative relationship between settlers and Indigenous peoples. This violent 'primitive accumulation' is the necessary condition for contemporary colonial forms of ground rent extraction (Coulthard, 2014; Marx, 1976 [1867]).

Yet the reality that cities are in fact Country is rarely remembered among settler scholars (Porter, 2018). If Indigenous peoples are remembered in public debate about urban casinos, they largely figure as vulnerable subjects, defined by perceived psychological deficits and subject to forms of racialized and paternalist government policy designed to prevent dangerous consumption (Nicoll, 2018). Any benefits Indigenous people receive from casino development in Australia come through the largess of casino magnates who may elect to target Indigenous people for employment in their businesses as an act of 'reconciliation' (Nicoll, 2018). But the irrefutable fact of the theft of Indigenous land further complicates the question of ground rent, for it raises the question of its just re-distribution. While the debt of unpaid reparations remains to be counted or repaid, decades-old demands for settlers to "pay the rent" will continue colour questions of ground rent in settler-colonial contexts.

\section{$\underline{\text { References }}$}

Adams PJ and Livingstone C. 2015. Addiction surplus: The add-on margin that makes addictive consumptions difficult to contain. International Journal of Drug Policy 26: 107-111.

Coulthard, G. S. 2014. Red Skin, White Masks: Rejecting the Colonial Politics of Recognition. Minneapolis: University of Minnesota Press. 
Harvey D. 2012. Rebel Cities: From the Right to the City to the Urban Revolution London: Verso.

Hannigan, J. 2007. Casino cities. Geography Compass, 1(4), 959-975.

Lowe, L. 2015. The Intimacies of Four Continents. Durham: Duke University Press.

Marx K. 1976 [1867]. Capital: A Critique of Political Economy, Volume 1, London: Penguin.

Marx K. 1981 [1894]. Capital: A Critique of Political Economy, Volume 3, London: Penguin.

Neal P, Delfabbro PH and O'Neil M. 2005. Problem Gambling and Harm: Towards a National Definition. Melbourne: Report prepared for the National Gambling Research Program Working Party.

Nicoll, F. 2018. Beyond the figure of the problem gambler: Locating race and overeignty struggles in everyday cultural spaces of gambling. Journal of Law and Social Policy, 30(1), 127149.

Peck J. 2016. Transatlantic city, part 1: Conjunctural urbanism. Urban Studies. 54(1): 4-30.

Peck J. 2017. Transatlantic city, part 2: Late entrepreneurialism. Urban Studies 54(2): 327-363.

Porter, L. 2018. From an urban country to urban Country: Confronting the cult of denial in Australian cities. Australian Geographer, 49(2), 239-246.

Said EW. 1979. Orientalism, New York: Vintage.

Stein, S. 2019. Capital City: Gentrification and the Real Estate State. Verso Books.

Walker, D. M. 2007. The Economics of Casino Gambling. Springer Science \& Business Media.

Wolfe, P. 2016. Traces of History: Elementary Structures of Race. Verso Books.

Young M and Markham F. 2017. Coercive commodities and the political economy of involuntary consumption: The case of the gambling industries. Environment and Planning A 49: 2762-2779. 